Stępniak-Kucharska A., The impact of the global downturn on the economic situation of the SME sector in Poland, „Ekonomia i Prawo. Economics and Law”, Polszakiewicz B., Boehlke J. (ed.), Vol. 15, No. 2/2016, pp. 235-248. DOI: http://dx.doi.org/10.12775/EiP.2016.015.

\title{
THE IMPACT OF THE GLOBAL DOWNTURN ON THE ECONOMIC SITUATION OF THE SME SECTOR IN POLAND
}

\author{
SUMMARY
}

Small and medium-sized enterprises play a leading role in modern economies - they create more than $50 \%$ of GDP, employ over $70 \%$ of people and are a major source of entrepreneurship (more than 99\% of entities belongs to the SME sector). The changes in the socio-economic system, initiated in Poland at the turn of 1989 and 1990, became the foundation for the development of entrepreneurship. Nowadays, companies from the SME sector have dominated the market over time and play a key role in the Polish economy. Small and medium-sized companies dominate in the domestic economy as they account for almost $99.9 \%$ of all enterprises. Their role in creating GDP is increasing - over the last 25 years, the share of SMEs' production in GDP almost doubled. The impact of the SME sector on the national economy can be also described through its participation in the creation of jobs. The SME sector is a major employer, employing more than $7.8 \mathrm{mln}$ workers. Therefore, it is important to examine the condition of small and medium-sized enterprises.

The purpose of this paper is to analyze the impact of the economic downturn on the financial condition of Polish non-financial SME companies. The survey covered such issues as: the number of active enterprises, number of persons employed and employees, revenues and production, profitability indicators, salaries and labour

Anna Stępniak-Kucharska, University of Lodz, Faculty of Economics and Sociology, Department of Economic Mechanism, ul. Rewolucji 1905 41, 90-214 Lódź, Poland, phone: +48 426355 514, e-mail: stepniak@uni.lodz.pl. 
productivity. The analyses were performed over the period 2003-2013. Data were obtained from Central Statistical Office of Poland.

Keywords: SME; enterprise; profitability; business fluctuations; economic condition JEL Classification: D22; E32; D92; L21

\section{INTRODUCTION}

Small and medium-sized enterprises play a leading role in modern economies - by number they dominate the world business stage. More than $95 \%$ of enterprises across the world are SMEs, accounting for approximately $60 \%$ of private sector employment ${ }^{1}$. In EU Countries over $96 \%$ of private firms belong to the SMEs sector. The highest proportion of SMEs among the industrialised countries has Japan - more than $99 \%$ of total enterprises are $\mathrm{SMEs}^{2}$. India, has over 13 mln SMEs, and in South Africa, it is estimated that 91\% of the formal business entities are SMEs ${ }^{3}$.

Poland does not differ in this regard from economies of other countries. The changes in the socio-economic system, initiated at the turn of 1989 and 1990, became the foundation for the development of Polish entrepreneurship. The creation of a free-market economy has led to a renaissance of Polish small and medium-sized enterprises, which have dominated the market over time. Nowadays, companies from the SME sector play a key role in the Polish economy, significantly affecting the development of basic economic indicators - they constitute more than $99 \%$ of all business entities, generate almost half of GDP and provide employment for almost 70\% of labour force.

A significant role of the SME sector makes the need to investigate how these enterprises respond to a downturn particularly important. The aim of the paper is to analyze the impact of the economic downturn on the financial condition of Polish non-financial SME companies. The survey covered such issues as: the number of active enterprises, number of persons employed and employees, revenues and production, profitability indicators, salaries and labour productivity.

${ }^{1}$ M. Ayyagari, A. Demirgüç-Kunt, V. Maksimovic, Small vs. Young Firms Across The World - Contribution to Employment, Job Creation, and Growth, "Policy Research Working Paper", No 5631/2011, p. 22.

2 The Economist, SMEs in Japan: A New Growth Driver?, London-New York 2010, p. 3.

3 J. Abor, P. Quartey, Issues in SME Development in Ghana and South Africa, "International Research Journal of Finance and Economics”, Vol. 39, No 218/2010, p. 28. 
The analysis, carried out in the period 2003-2013, was conducted on the basis of statistical data published by the Polish CSO in Activity of non-financial enterprises.

\section{THE CURRENT STATE OF KNOWLEDGE - TRANSMISSION OF THE ECONOMIC DOWNTURN TO THE POLISH ECONOMY}

The economic crisis that spread from the USA to other countries did not reach emerging markets general, and Central Europe particular, as strongly as the economies of developed countries ${ }^{4}$. Poland was hit by the economic downturn to the slightest extent out of all the Community countries, and it was (and has) remaining during the crisis a country the only member state of the EU with growing $\mathrm{GDP}^{5}$. Low vulnerabilities have defined it as a "green island".

Initial high resilience of the Polish economy to the global crisis was mainly due to the fact that sources of the crisis were external, not internal. In that situation, weak links with the US economy and its banking and financial sector meant that Poland did not suffer its consequences directly. Additionally, a relatively stable situation of the Polish banking system (a low proportion of non-performing loans, almost absent "toxic assets") ${ }^{6}$ and a large, relatively stable internal market which is the recipient of most domestic production contributed to that state of affairs. Moreover, a dynamic development of the service sector, the manufacturing and construction industries, led to a steady increase in the labour market.

Changes in the global economy proved to be too deep, however, for Poland or any other country to protect itself. The transmission mechanism of crisis phenomena, which reached Poland with some delay, worked mainly through two channels i.e. financial markets and foreign trade. The first signs of the economic downturn were visible at the turn of the year 2008 and 2009. This was mainly due to the rapid deterioration of the economic situation of our most important trading partners. There was a sharp decrease

${ }^{4}$ K.A. Soos, Polish and Hungarian SMEs facing the crisis, [in:] B. Dallago, C. Gulielmetti (eds.), The consequences of the international crisis for European SMEs. Vulnerability ad resilience, Routlege, Oxford 2012, pp 156-157.

${ }^{5}$ European Commission, Economic Crisis in Europe: Causes, Consequences and Responses, "European Economy", Vol. 7/2009, p. 27.

${ }^{6}$ J. Adamiec, P. Russel, Światowy kryzys gospodarczy a sektor przedsiębiorstw i gospodarstw domowych w Polsce Kryzys finansowy. Wybrane zagadnienia, Wydawnictwo Sejmowe, Warszawa 2009, pp. 12-13. 
in exports of Polish enterprises and a withdrawal of foreign investors from the capital market. The crisis in developed countries generally leads to a decline in confidence in emerging economies considered less safe. It results in an outflow of capital from these countries, which leads to depreciation pressure and increasing volatility in the foreign exchange market ${ }^{7}$.

Paradoxically, however, the depreciation of the Polish zloty had a positive impact on improving international competitiveness of Polish enterprises and thus the foreign trade balance. Hence, the decline in the value of exports was not as rapid as the initial decline in demand in the countries first affected by the crisis. Those phenomena allowed Poland to achieve the GDP growth of $1.7 \%{ }^{8}$, unique among EU Member States and other developed economies. The GDP growth was also positively influenced by consumption, which is a major driving force of the Polish economy.

\section{THE METHOD OF RESEARCH}

The analysis, carried out in the period 2003-2013, was conducted on the basis of statistical data published by the Polish CSO in Activity of non-financial enterprises.

The research sample comprises legal persons, entities without legal personality, and natural persons, which conducted economic activity in Poland in the years 2003-2013. The group of analyzed entities do not include units classified to section A (Agriculture, forestry and fishing), K (Financial and insurance activities) and $\mathrm{O}$ (Public administration and defense; compulsory social security).

The data were derived by CSO from a sample survey on the entities regarded as microenterprises (with up to 9 persons employed), as well as from two exhaustive surveys on remaining entities (depending on the type of activity).

7 A. Wojtyna, Gospodarki wschodzqce w obliczu kryzysu finansowego: duża odporność czy podatnośc??, "Gospodarka Narodowa”, No. 9/2010, p. 31.

${ }^{8}$ Ministerstwo Gospodarki, Koniunktura gospodarcza w wybranych krajach w okresie kryzysu finansowego, Warszawa 2011, pp. 38-41. 


\section{THE RESEARCH PROCESS AND THE RESULTS OF RESEARCH}

\subsection{SMES BEFORE THE ECONOMIC DOWNTURN}

By 2008, the economic condition of the Polish SME sector systematically improved due to three main factors: the good condition of the Polish economy, worldwide economic boom and an inflow of EU structural funds. This period is considered to be good times for the economic and business development of enterprises, including the establishment of new businesses.

Poland's accession to the European Union has affected companies in two ways. On the one hand, the elimination of many pre-existing non-tariff barriers protecting Polish producers against foreign competition has forced companies to increase competitiveness and innovativeness. On the other hand, Polish companies have gained easier access to international markets. Access to financial support in the framework of the Structural Funds has also been an opportunity for the Polish economy, especially SMEs.

Generally, as a result of accession, stabilization of quantitative and qualitative development of the Polish SME sector occurred. Over five years, the number of active entities increased by $7.9 \%$, the number of jobs by $13.6 \%$ and revenues by $37.5 \%$ (revenues per enterprise by $27.4 \%$ ) (figure 1). Positive changes also occurred in the case of gross turnover profitability, gross profit $(+75.8 \%)$ and labour productivity ${ }^{9}(+28 \%)$.

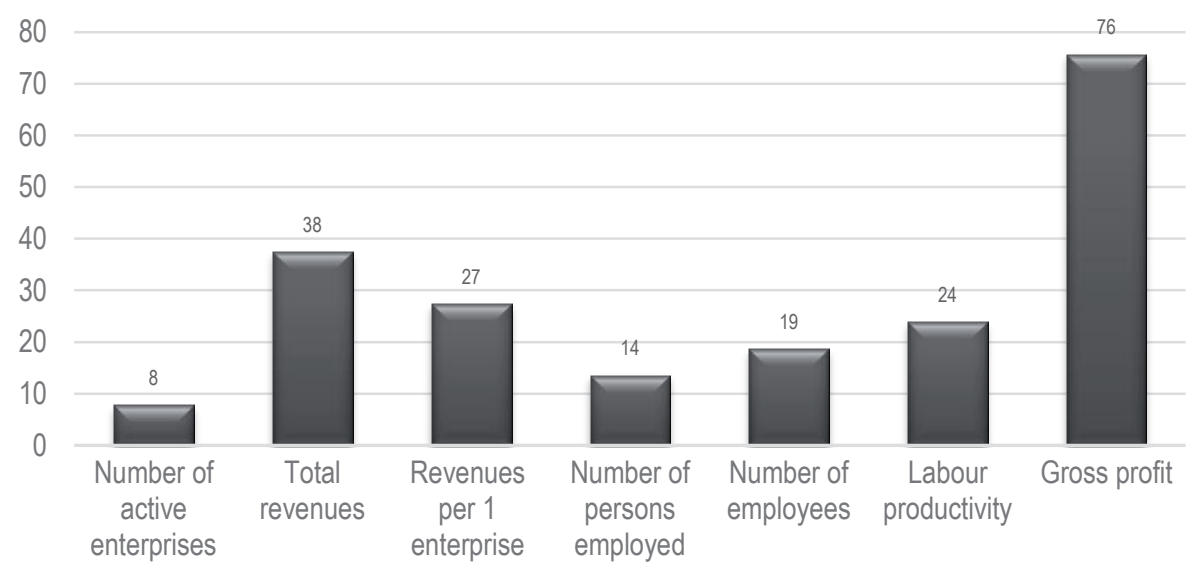

Figure 1. Changes in economic indicators of Polish enterprises in the years 2003-2008 (in \%)

Source: Own preparation based on Gtówny Urząd Statystyczny, Działalność przedsiębiorstw niefinansowych, Warszawa, 2004-2014.

${ }^{9}$ Calculated as the ratio of revenues to the number of employed. 
The analysis of enterprises taking into account their size indicates this determinant has an important impact on changes in various areas of their operations. Medium-sized enterprises showed the largest increase in total revenues and one company recorded an increase in labour productivity and average wages. Small businesses dominated in terms of the number of active entities and creating new jobs. A characteristic feature of micro enterprises was, however, a significant increase in gross profit, and thus the pre-tax operating profit margin (GTP).

\subsection{THE ECONOMIC DOWNTURN IN POLISH SMES}

The drastic economic downturn in the country and foreign markets affected the financial condition of enterprises. In 2009 almost all the studied parameters deteriorated ${ }^{10}$ (figure 2 ). The changes, however, especially compared to the USA and other EU countries, were not so deep. The crisis meant that within a year the number of companies active in the SME sector fell by $10.2 \%$. This was caused primarily by the self-cleansing of the market and also by a decrease in the number of newly registered entities.

Unfavourable changes also occurred in the labour market - the number of persons employed fell by $5.9 \%$ and employees by $3.7 \%$. The relationship between changes in both parameters seems interesting. SMEs are the major employers of non-standard forms of employment. However the situation of these workers is very fragile in SMEs. It is assumed that in times of crisis, persons employed on non-standard forms of employment are first to be laid off $^{11}$. In Poland, however, the opposite trend was visible - the number of jobs diminished more quickly than employment. This was due to the before-mentioned processes of self-cleansing (owners of one person companies) but also to the fact that to optimise labour costs entrepreneurs first laid off the most cost-intensive employees, i.e. the ones on employment contracts.

10 The only exception are wages steadily increasing since 2003 regardless of the company size.

${ }_{11}$ V. Bussat, Restructuring in SMEs: networks and social dialogue. Transverse analysis, [in:] V. Bussat, C.E. Triomphe, B. Köper (eds.), Crisis, Social dialogue and Renewals in Restructuring. Restructuring in SMEs, http://responsible-restructuring.eu/wp-content/uploads/2013/12/ RespRest-WC2-Anglais.pdf

(29.09.2015), p. 70 . 


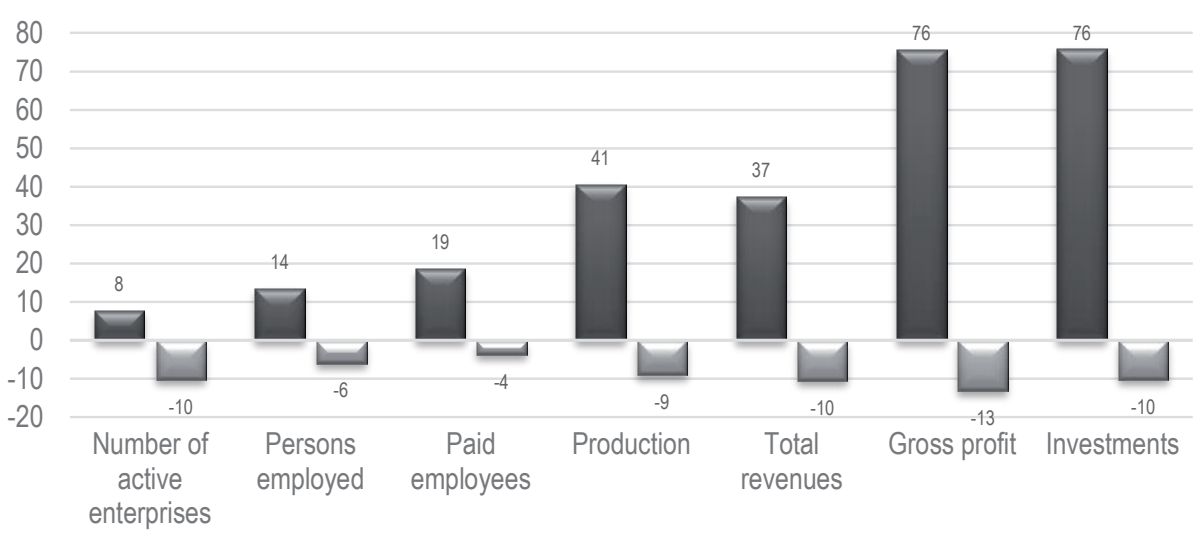

口2008/2003

$\square 2009 / 2008$

Figure 2. Number of active enterprises of the Polish SMEs sector in 2003-2013 (in \%)

Source: Own preparation based on Główny Urząd Statystyczny, op. cit.

The year 2009 also saw a reduction in production (by 8.9\%), revenues (by $10.4 \%$ ), gross profit (by 13.1\%), capital expenditures (by 10.2\%), labour productivity (by 5.3\%) and gross turnover profitability of SMEs. However, since the decline in the number of active companies was greater than the decline in production and revenues, in 2009 the average value of production per one enterprise increased by $1.4 \%$ and revenues fell by only $0.2 \%$. A similar situation occurred with investment expenditures - they were reduced by only $0.04 \%$.

Wages, which systematically increased, were the only area in which the downturn did not lead to unfavourable changes, although there was a weakening of their growth in 2009.

The analysis of the particular groups of companies in the SME sector indicates the level of their response to the economic downturn varied. Small businesses were the most resilient to economic changes. Declines in most of the indicators in this group were the smallest and their financial standing improved most rapidly. Micro enterprises turned out to be the most vulnerable to changes in economic conditions. Declines in the value of the studied parameters were generally the highest. In addition, this group failed to return to the pre-crisis condition.

The year 2009 saw a decrease in economic activity as there was a reduction in the number of companies in all the analysed groups of entities (figure 3). There was, however, a clear relationship between the size of enterprises in the SME sector and the number of liquidated companies - the larger the company, the weaker its response to the downturn. The biggest decline 
occurred among micro enterprises (10.26\%), while the smallest decrease was recorded among medium-sized ones (-3.18\%). Importantly, this group turned out to be more resilient to the economic downturn in this regard than large enterprises (a decrease of $4.27 \%$ ).

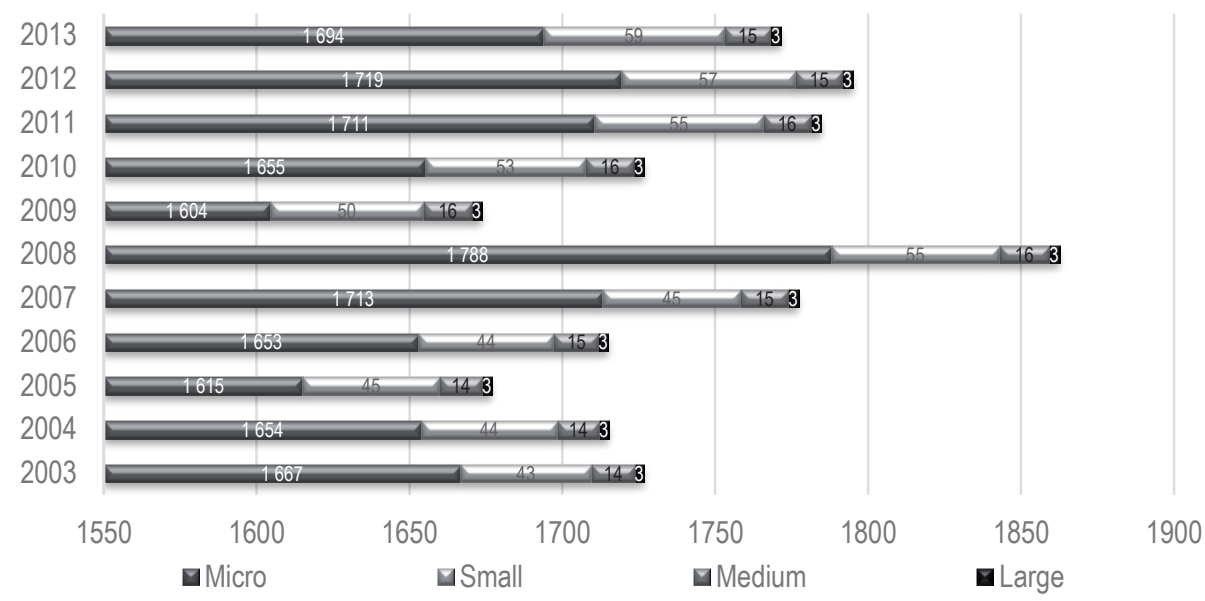

Figure 3. Number of active enterprises of the Polish SMEs sector in 2003-2013 (in ths.)

Source: Own preparation based on Główny Urząd Statystyczny, op. cit.

A similar situation occurred with SMEs' role related to creating jobs (figure 4). The largest decline in the number of employed occurred in micro enterprises (7.06\%) and the smallest decrease in medium-sized enterprises $(3.23 \%)$.

It is important to note that the SME sector was less vulnerable in this respect than large entities (-9.55\%). Declines were much smaller in the area of employment. Additionally, the smallest companies reduced the level of employment to the slowest and lowest degree $(-2.65 \%)$. The largest decrease in employment levels was observed in large $(-6.12 \%)$ and small enterprises $(-5.98 \%)$. The differences in the level and trend shaping these values, as mentioned earlier, may arise from the fact that micro enterprises are mainly one person companies, relying solely on their owners' work, and that their revenues come exclusively from the provision of work for other companies without incurring work-related costs ${ }^{12}$. Thus, liquidation of such activities leads to a reduction in the number of jobs but not necessarily employment.

12 Polska Agencja Rozwoju Przedsiębiorczości, Raport o stanie sektora matych i średnich przedsiębiorstw w Polsce w latach 2010-2011, Warszawa 2012, p. 67. 

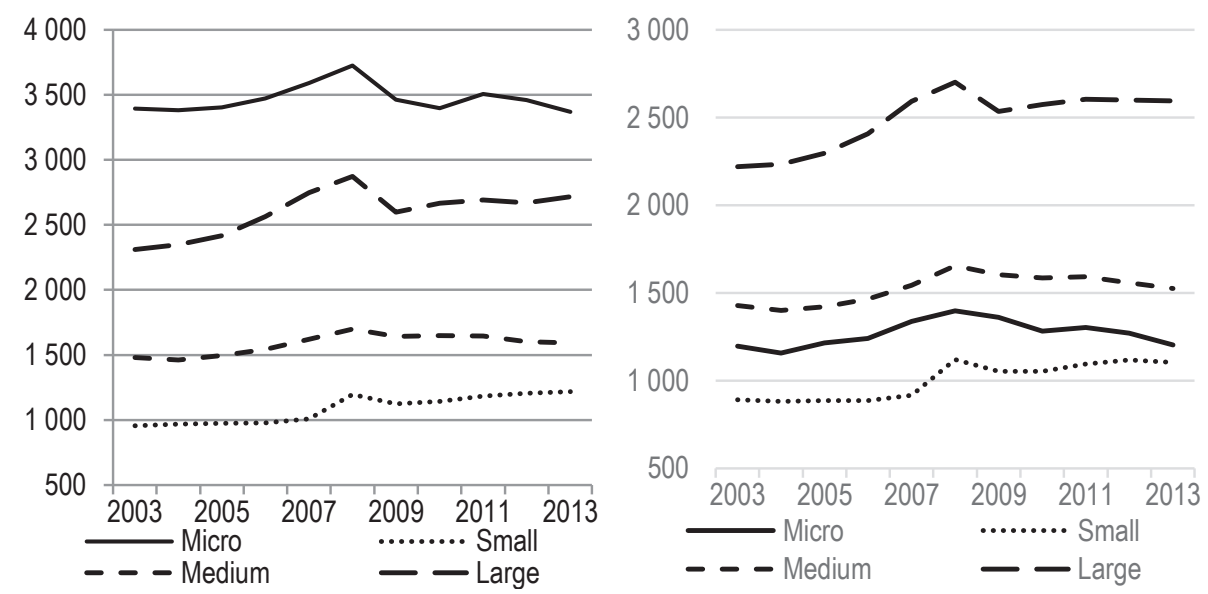

Figure 4. Number of persons employed (left figure) and employees (right figure) of Polish enterprises in 2003-2013 (in ths.)

Source: Own preparation based on Gtówny Urząd Statystyczny, op. cit.

The economic downturn also caused declines in production levels and revenues (figure 5). The relationship between the overall level of production and revenues per enterprise is, however, interesting. 2009 saw a decrease in both values, yet in the case of the analysis covering revenues and production levels per enterprise, the situation looks different. Generally, revenues per enterprise in the SME sector increased by $1.39 \%$. However, this was due to an increase in the average income in micro enterprises (2.14\%). The remaining groups of enterprises recorded declines in this area (the larger the company, the greater the decrease).

The analysis of revenues indicates a similar trend - micro enterprises showed a slight increase (of 0.80\%). Moreover, revenues grew both in real and nominal terms. Small and medium-sized enterprises saw a decline in average revenues. Medium-sized entities, however, responded more strongly to the downturn $(-6.48 \%)$ than the small ones $(-4.80 \%)$.

The unusual situation of micro enterprises, however, was not permanent and did not stem from their very low vulnerability to the economic downturn but from a delayed response. Over the next three years, micro enterprises, as the only group of companies, recorded a systematic decrease in revenue and production levels. 

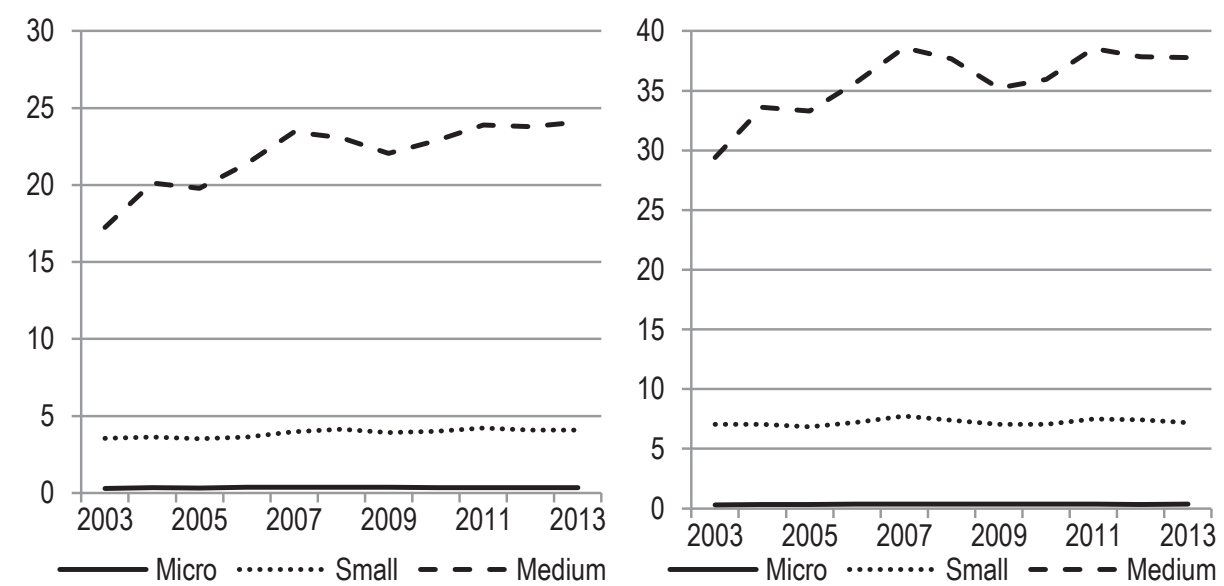

Figure 5. Production (left figure) and revenues value (right figure) per enterprise of the Polish SME sector in 2003-2013 (in mln PLN, constant prices 2003)

Source: Own preparation based on Główny Urząd Statystyczny, op. cit.

The decrease in production and revenues accompanied by an increase in costs led to a reduction in the SME sector's profitability (figure 6). Over one year, the overall level of revenues fell by more than $13 \%$. It should be remembered, however, that the data relate to entities that generate a financial surplus. The analysis of gross turnover profitability ratio (GTP) indicates that in 2009 only the profitability of micro enterprises was reduced (by $0.5 \mathrm{pp}$ ). Medium-sized and large companies showed a rise in the GTP level. It should be noted, however, that it resulted from the decline recorded a year earlier.

Changes in the production level and the number of employed led to changes in labour productivity. Overall productivity of SMEs fell by $3.21 \%$, primarily as a result of reducing the productivity of small businesses $(-7.4 \%)$. Micro enterprises $(-1.38 \%)$ and medium-sized enterprises $(-4.32 \%)$ recorded a much smaller decrease in productivity. Interestingly, large enterprises saw then an increase of $3.26 \%$ in labour productivity ${ }^{13}$.

13 More on SMEs' productivity in: A. Stępniak-Kucharska, Zatrudnienie i wydajnośc pracy polskiego sektora MSP w okresie dekoniunktury gospodarczej, [in:] A. Organiściak-Krzykowska, K. Nyklewicz (eds.), Rynek pracy w dobie innowacji, Uniwersytet Warmińsko-Mazurski-IPiSS, Olsztyn-Warszawa 2014. 

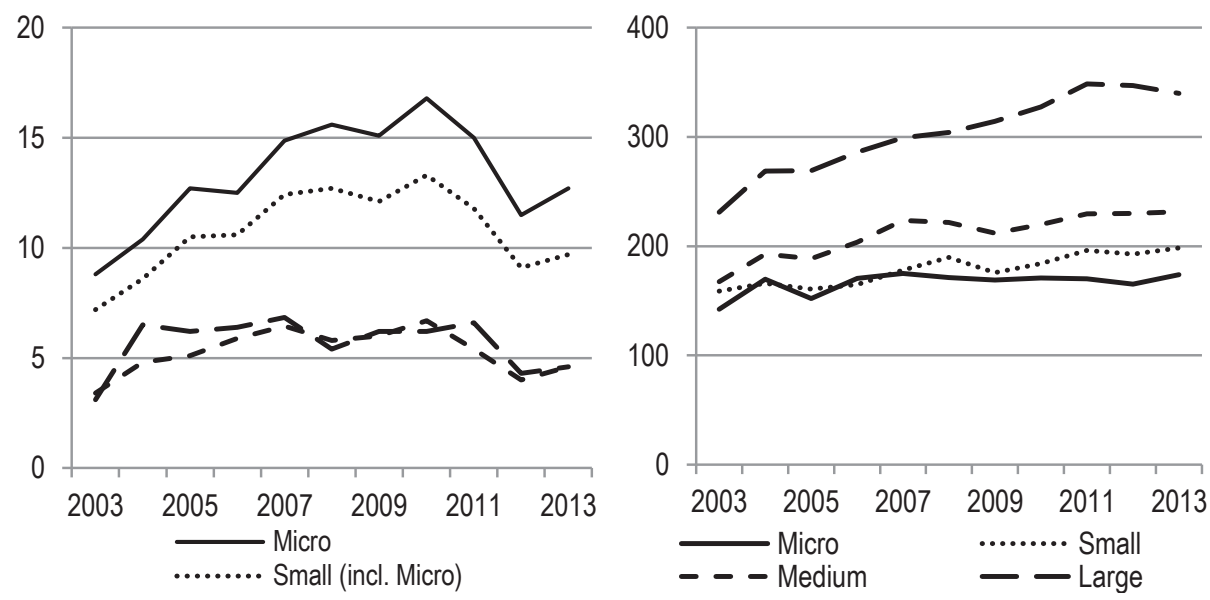

Figure 6. Gross turnover profitability (left figure) and labour productivity (right figure) of Polish enterprises in 2003-2013 (\%, in ths. PLN, constant prices 2003)

Source: Own preparation based on Główny Urząd Statystyczny, op. cit.

\subsection{AFTER THE ECONOMIC DOWNTURN}

The deterioration of the economic situation of Polish enterprises was not very deep and only short-term as in 2010 an improvement in their condition was evident. In general, statistics show there was a further deterioration in the condition of the SME sector at the time (a decline in revenues and production, as well as the number of employed and employees). The analysis of the condition of particular groups of enterprises indicates, however, that the overall performance of the SME sector was undercut by micro enterprises. As mentioned earlier, this group experienced unfavourable trends with some delay (2010-2012). Thus, the overall performance of SMEs was determined by their condition (a further decrease in revenues, production, employment and number of employed, accompanied by the largest increase in GTP). In the other groups of entities (small and medium-sized ones), there was a clear improvement in the financial condition in 2010 - an increase in all the analysed parameters ${ }^{14}$. Medium-sized enterprises regained their balance much faster as they recorded a higher increase in revenues $(2.05 \%)$, production $(3.79 \%)$ and gross profit (15\%). In the group of small businesses much stronger growth in economic activity (4.79\%), the number of jobs created $(1.80 \%)$ and employment $(+0.02 \%)$ was seen. Despite the fact that small and

${ }^{14}$ A decline in employment of $1.28 \%$ was recorded only in the group of medium-sized enterprises. 
medium-sized enterprises showed increasingly better financial standing, they fared much worse than large enterprises.

In the following years there were fluctuations in the economic condition of the Polish SME sector. In 2011, further growth of the parameters was visible but a year later they declined (only the number of enterprises and average wages increased). In the last year of the analysis (2013) there was another noticeable improvement in the situation of SMEs.

Although Polish companies weathered the downturn relatively well, at least in comparison with other countries in the EU and the world, they failed to regain their pre-crisis positions. At the end of 2013, compared to 2008, the Polish SME sector recorded only a higher number of active companies and a higher level of labour productivity (figure 7), as well as steady growth in average wages. The group of large enterprises, in which only four analysed parameters were lower (the number of companies, the number of employed and employees, GTP), exhibited much better performance.

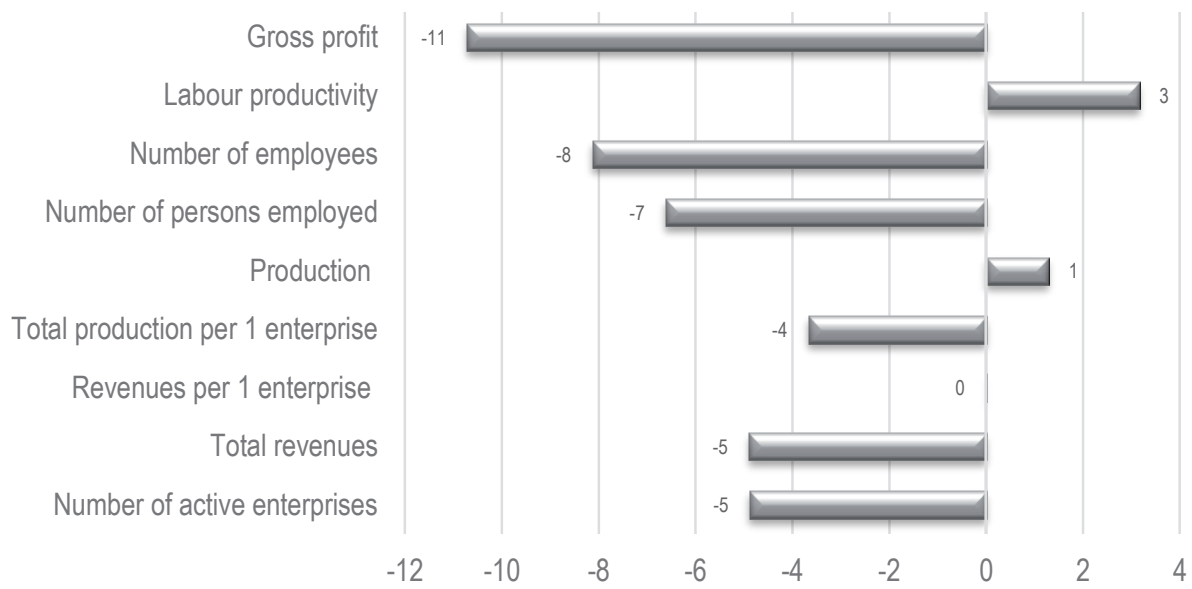

Figure 7. Changes in economic indicators for the Polish SME sector in 2008-2013 (in \%)

Source: Own preparation based on Główny Urząd Statystyczny, op. cit.

The situation of SMEs, however, varied significantly. The most resilient to economic changes were small businesses. In the case of most of the indicators, declines were the lowest and their financial standing improved most quickly. Eventually, in 2013, as many as 6 analysed parameters in this group were higher than in 2008 (the number of companies - 7.56\%, total revenues $-4.57 \%$, production per enterprise $-6.48 \%$, the number of employed $1.9 \%$, labour productivity $-4.46 \%$, average wages $-10.49 \%)$. In addition, a decrease in the remaining values was the lowest in the SME sector. 
Medium-sized enterprises turned out to be less resilient to the crisis. Only four parameters were higher in this group: revenues per enterprise $(+0.28 \%)$, total production $(+4.40 \%)$ as well as the mentioned earlier labour productivity $(+4.53 \%)$ and average wages $(+6.17 \%)$.

Micro enterprises proved to be the most vulnerable to changes in economic conditions. In the period of downturn, they recorded the largest declines (though one year later). In addition, micro enterprises failed to return to the pre-crisis condition. At the end of 2013, they recorded only a higher level of labour productivity and wages. It should be noted, however, that the average wage in this group of companies is the lowest and it is close to the minimum wage ${ }^{15}$. The growth of this parameter resulted mainly from an increase in the minimum wage - in the years 2008-2013 the average gross wage in micro enterprises increased by $12.39 \%$ and the minimum wage by $42 \%$.

\section{CONCLUSIONS}

The condition of the SME sector, which plays a leading role in most economies, and its response to the economic downturn in particular is very important. The deterioration of the economic situation of this group of enterprises causes major changes in the real economy, especially the labour market.

The analysis presented indicates that the global crisis that reached Poland with some delay had a relatively mild impact on Polish companies. It led to a reduction in basic parameters (revenues, production, profitability, the number of persons employed and employees), the declines, however, were mild and short-term. Micro-enterprises, which recorded the largest decreases, proved to be by far the most vulnerable to the crisis. In addition, they were unable to return to the situation before the downturn. Small businesses were the least vulnerable.

High resilience of Polish enterprises to the economic downturn resulted, among others, from the fact that Polish SMEs are particularly active in services and trade, hence they depend on domestic demand rather than exports. Small businesses in Poland operate in relatively safe market niches. Moreover, the government took a number of initiatives (a stimulus package) supporting Polish companies in order to maintain economic activity during the crisis.

15 The average gross wage in 2013 was 2.210 PLN with the minimum wage at the level of 1.600 PLN. 


\section{BIBLIOGRAPHY}

Abor J., Quartey P., Issues in SME Development in Ghana and South Africa, "International Research Journal of Finance and Economics", Vol. 39, No 218/2010.

Adamiec J., Russel P., Światowy kryzys gospodarczy a sektor przedsiębiorstw i gospodarstw domowych w Polsce Kryzys finansowy. Wybrane zagadnienia, Wydawnictwo Sejmowe, Warszawa 2009.

Ayyagari M., Demirgüç-Kunt A., Maksimovic V., Small vs. Young Firms Across The World - Contribution to Employment, Job Creation, and Growth, "Policy Research Working Paper”, No 5631/2011, http://dx.doi.org/10.1596/1813-9450-5631.

Bussat V., Restructuring in SMEs: networks and social dialogue. Transverse analysis, [in:] V. Bussat, C.E. Triomphe, B. Köper (eds.), Crisis, Social dialogue and Renewals in Restructuring. Restructuring in SMEs, http://responsible-restructuring.eu/wp-content/uploads/2013/12/RespRest-WC2-Anglais.pdf (29.09.2015).

European Commission, Economic Crisis in Europe: Causes, Consequences and Responses, "European Economy", Vol. 7/2009.

Główny Urząd Statystyczny, Działalność przedsiębiorstw niefinansowych, Warszawa, 2004-2014.

Ministerstwo Gospodarki, Koniunktura gospodarcza w wybranych krajach w okresie kryzysu finansowego, Warszawa 2011.

Polska Agencja Rozwoju Przedsiębiorczości, Raport o stanie sektora matych $i$ średnich przedsiębiorstw w Polsce w latach 2010-2011, Warszawa 2012.

Soos K.A., Polish and Hungarian SMEs facing the crisis, [in:] B. Dallago, C. Gulielmetti (eds.), The consequences of the international crisis for European SMEs. Vulnerability ad resilience, Routlege, Oxford 2012.

Stępniak-Kucharska A., Zatrudnienie i wydajność pracy polskiego sektora MSP w okresie dekoniunktury gospodarczej, [in:] A. Organiściak-Krzykowska, K. Nyklewicz (eds.), Rynek pracy w dobie innowacji, Uniwersytet Warmińsko-Mazurski-IPiSS, Olsztyn-Warszawa 2014.

The Economist, SMEs in Japan: A New Growth Driver?, London-New York 2010.

Wojtyna A., Gospodarki wschodzace w obliczu kryzysu finansowego: duża odporność czy podatnośc??, "Gospodarka Narodowa”, No. 9/2010. 